\title{
Threshold effect of public debt on economic growth: An empirical analysis in the European transition countries*
}

\author{
Besnik Fetai ${ }^{1}$, Kestrim Avdimetaj ${ }^{2}$, Abdylmenaf Bexheti ${ }^{3}$, \\ Arben Malaj ${ }^{4}$
}

\begin{abstract}
The paper empirically examines and assess the relationship between public debt and economic growth in the European transition countries from 1995 to 2017 (both years inclusive). The study attempts to identify and determine the threshold values or the extent to which public debt-to-GDP ratio has a positive effect on economic growth, and beyond which point debt-to-GDP ratio has a negative effect on the economic growth in European transition countries. For this purpose, we employ different econometric models and techniques such as pooled OLS, fixed and random effects models, GMM (Generalized Method of Moments), and bootstrap method in order to determine threshold values of public debt-to-GDP ratio. The findings prove the general theoretical assumption that at low level of public debt- to-GDP ratio has a positive effect on economic growth, whereas
\end{abstract}

\footnotetext{
* Received: 23-05-2020; accepted: 09-12-2020

1 Professor of Economics, South East European University, Faculty of Business and Economics, Ilindenska, n.135, 1200, Tetovo, The Republic of North Macedonia. Scientific affiliation: economics, macroeconomics, monetary policy, fiscal policy, and econometrics. Phone: +389 71-915-463.E-mail:b.fetai@seeu.edu.mk.

2 Assistant Professor of Economics, University for Business and Technology, Faculty of Management and Business and Economics, Kalabria Road, 10000, Prishtine, The Republic of Kosovo. Scientific affiliation: economics, financial economics, macroeconomics, econometrics. Phone: +383 45-482-428. E-mail: kestrimavdimetaj@gmail.com.

3 Professor of Economics and Finance, South East European University, Faculty of Business and Economics, Ilindenska, n.135, 1200, Tetovo, The Republic of North Macedonia. Scientific affiliation: applied economics, macroeconomics, monetary economics and public finance. Phone:+389 70-364-169. E-mail: a.bexheti@seeu.edu.mk.

3 Professor of Finance, Institute for Public Policy and Good Governance, University of Tirana, Faculty of Economics, Mother Tereza, n.183, 1001, Tirana, The Republic of Albania. Scientific affiliation: public policy, monetary economics and financial market. Phone: + 355 69-207-4620. E-mail: arben.malaj@gmail.com.
} 


\begin{abstract}
beyond a certain turning point a negative effect on growth prevails in the European transition countries. In addition, the results show different levels of threshold values of public debt-to-GDP ratio among European transition countries. So far, it is confirmed that for less developed European transition countries the threshold values of the debt-to-GDP is lower than for more developed ones in the sample. Therefore, the findings provide additional information for European transition countries, which have debt levels above the threshold values, as to reduce their public debt and to support long-term economic growth prospects.
\end{abstract}

Key words: Economic growth, public debt, turning point, panel data, European transition countries

JEL classification: E60, E69, E011, H63

\title{
1. Introduction
}

There is a mountain of empirical studies that have investigated the relationship between public debt and economic growth. However, the empirical evidence is still inconclusive and debatable regarding the threshold of the public debt. Most of the studies show that lower public debt or debt below a certain threshold value has positive effect on economic growth (Reinhart and Rogoff, 2010; Baum et al., 2013; Woo and Kumar, 2015; Taylor et al., 2012; Irons and Bivens, 2010; Pescatori et al., 2014; Rankin and Roffia, 2003; Mencinger et al., 2015; Bexheti et al., 2020). Surprisingly, only a few studies have examined the issue of public debt, and how the threshold value of public debt affects economic growth in transition countries, particularly in European transition countries (Mencinger et al., 2015; Checherita and Rother, 2010; Bexheti et al., 2020). European Transition countries have been faced with several problems including war, political instability, hyperinflation, high public debt and the collapse oftheir financial sector. In the process of transitioning; these countries now offer an interesting case study, particularly with regard to relationships between publc debt and economic growth. Therfore, the research question of this paper is to examine the public debt threshold value and its effect on economic growth in the European transition countries. To examine the relationships between public debt-to GDP ratio and economic growth we propose two following research hypotheses:

H1: The hypothesis of this paper is that debt-to-GDP ratio below certain point of threshold value has a positive impact on economic growth, whereas debt-to-GDP ratio beyond certain point of threshold value has a negative impact on economic growth in the European transition countries.

H2: The threshold value of debt-to-GDP ratio is lower for less developed European transition countries than developed ones in our sample.

To search for threshold values to public debt-to GDP ratio, we employ different econometric models and techniques such as pooled OLS, fixed and random effects model, GMM (Generalized Method of Moments), and bootstrap approach. The 
data, for this paper have been collected from World Bank, International Monetary Fund, and Eurostat. The main argument for this study is that only a few studies have examined the threshold value of public debt and its effect on economic growth in European transition countries (Mencinger et al., 2015; Checherita and Rother, 2010; Bexheti et al., 2020), hence, a gap exists in the literature that this study seeks to fill. However, they have not showed clear methodology regarding identification of the threshold value of public debt. Our study differs from them, as we employ panel threshold model proposed by Hansen (1999) in order to identify threshold value of public debt in the European transition countries.

To summarize, the findings of this study show that the debt-to-GDP ratio turning point are $81.60 \%$ of GDP in Central Europe countries, $71.90 \%$ of GDP in Eastern Europe countries, and $58.20 \%$ of GDP in Western Balkans countries. That is any increase of public debt-to-GDP ratio up to this interval has positive impact on economic growth, and beyond this interval, the positive affect inverts to have a negative effect on economic growth in the European transition countries. Another interesting issue is that, squaring debt will also negatively affect economic growth in the European transition countries.

The reminder of this paper is organized as a follow: Section 2 reviews of literature; Section 3 presents research methodology and data; Section 4 provides the results and discussion, and Section 5 provides the findings and conclusion.

\section{Literature review}

There are several authors who have examined the effect of public debt threshold value on economic growth, both developed, and countries in transition (Checherita and Rother, 2010; Baldacci and Kumar, 2010; Egert, 2013; Wigger, 2009; Baum et al., 2013; Schclarek, 2004; Adam and Bevan, 2005). However, there are only few studies that have examined the public debt threshold value and its effect on economic growth in countries in transition, particularly the European countries. Noted is the fact that the empirical evidence does show consensus relating to the public debt threshold value and its effect on economic growth. The study by Mencinger et.al. (2015) found that the public debt threshold in developed countries is ranged from $90 \%$ to $94 \%$, which means that above this public debt threshold, it will have a negative effect on economic growth. However, the public debt threshold below $90 \%$ will have a positive effect on economic growth. In addition, the findings show that public debt threshold limit in developing countries is ranged from $44 \%$ to $45 \%$, below this limit the public debt will have positive effects on economic growth, while above this limit it will have a negative impact on economic growth. These findings suggest that there is a difference between developed and developing countries with regard to the relationship between public debt and threshold value. 
The study by Checherita and Rother (2010) examined the public debt threshold in the EU countries and found that the public debt threshold value ranged from $82 \%$ to $91 \%$. If the public debt is above this threshold, it will have a negative effect on economic growth in EU countries. On the other hand, if the public debt remains below the threshold value of $82 \%$, it will have a positive impact on economic growth, and will foster the economic growth on these countries. Reinhart and Rogoff (2010) investigated the impact of public debt on real long-term GDP growth rates, taking into account a sample of 24 developing countries, over a period of nearly 200 years (1790-2010). They have found that the public debt may have positive effect on economic growth in the short run, while in the long run the public debt has been rated as negative by systematically curbing the growth and economic development of these countries. In addition, Baldacci and Kumar (2010) examined the impact of fiscal deficits and public debt on long-term interest rates during 1980 2008, taking into account a wide range of country-specific factors for a panel of 31 advanced and emerging market economies. The authors found that higher deficits and public debt lead to a significant increase in long-term interest rates, which in turn lead to decrease of economic growth.

Research study by Panizza and Presbitero (2014) analyzed the linkages between growth, public debt and productivity in the 155 countries over the period 19702008. The authors found that there is a negative effect of debt ratio to GDP and financial crisis on economic growth. Afonso and Alves (2015) analyzed the effects of sovereign debt-to-GDP ratio on economic growth for 14 European countries over 43 years (1970-2012). The study concluded that government debt has a negative effect on economic growth, both, in the short and long-term. This contrast with Panizza and Presbitero (2013) who showed that there is no evidence that debt has an effect on economic growth and there are different ways through which a large public debt may harm the economy.

Research by Ghosh et al. (2013) examined empirically a sample of 23 advanced economies over 1970-2007 and found robust empirical support for the fiscal fatigue characteristic. They found that the marginal response of primary budget balance to lagged debt is nonlinear, remaining positive at moderate debt levels but starting to decline when debt reaches around 90-100 percent of GDP. Furthermore, they found that the estimated debt limits and corresponding fiscal space vary considerably across countries. For example, the debt limit obtained for countries in the sample ranges between 150 to 250 percent of GDP, while the fiscal space estimates indicate limited or no available fiscal space for Greece, Iceland, Italy, Japan and Portugal, and ample space for Australia, Korea and the Nordic countries. Gnegne and Jawadi (2013) analyzed public debt and its dynamics for the UK and the USA, and public debt proved to be asymmetric and nonlinear making the authors conclude that public debt seems to be based on several threshold effects, which helps to understand its dynamics with more accuracy. On the other hand, Schclarek 
(2004) found that a significant relation between the government debt and economic growth could not be identified for the industrialized countries. For the developing countries, low levels of external debt are associated with higher growth rates. The reverse is not caused by private external debt, but rather by the incidence of public external debt.

Study by Bexheti et al. (2020), investigated the impact of public debt on economic growth, employing panel data, 2OLS and panel VAR, over the period 2003-2016, in the Western Balkans Countries. The result showed that the public debt has a week negative effect on economic growth and the coefficient is statistically significant only in random approach and 2OLS. Moreover, they found that threshold value of public debt is $50,87 \%$, however, there was not clear methodology by which they have identified threshold value in their study.

To summarize, it is clear that a considerable number of studies have analyzed the effect of the public debt on economic growth in developed countries. However, there are very few empirical studies addressing the relationship between public debt and economic growth in countries in transition, especially in European transition countries. This paper will attempt to contribute to the issue, by investigating how growth of public debt, will affect the economic growth in the European transition countries. This research will also attempt to determine the optimal threshold value, and to what level does the increase of public debt to GDP ratio affects positively the economic growth of the European transition countries.

\section{Methodology}

In order to explore relationships between debt-to-GDP ratio and economic growth we employ panel data model such as OLS, fixed and random effect models, Hausman-Taylor IV and GMM. In addition, we employ panel threshold model proposed by Hansen (1999) in order to identify the threshold values of debt-to-GDP ratio.

\subsection{Research Methodology}

\section{(i) Panel Data Model}

The empirical analysis contains panel data from 1995 to 2017 (approximately 22 years) for 20 European transition countries, specifically countries in Central Europe, Eastern Europe, and the Western Balkans. The dynamic panel model (GMM) are employed to test the relationships between debt to GDP and GDP per capita and other independent variables in the European transition countries. We apply Arellano and Bond (1991), Blundell and Bond (1998), Blundell et al. (2000) GMM estimator 
as it is proper estimator. The GMM procedure also allows us to control for problem of endogeneity bias caused by reverse causality running from GDP per capita to debt to GDP and other explanatory variables. In order to deal with endogeneity problem, we employ instrumental variable (IV) or two steps GMM estimators instrumental (IV). It is relatively common practice with macroeconomics data to use the lagged debt to GDP ratio and the lagged debt to GDP ratio squared as instruments with two lags. This instrument has the advantage of not havening a direct causation effect on the growth rate, if it is assumed that there are not spillover effects between debt levels in European transition countries. The endogeneity problem is also avoided in our specification because independent variables are all lagged 1 or 2 years compared to the dependent variable. Furthermore to determine the public debt threshold value, we used the "bootstrap" estimator, which is based on a very high number of simulations. For the comparison purpose, we apply and OLS, fixed effect model and random effect model.

The reliability of the GMM estimator depends on the validity of its instrument sets. To address this issue, we consider two specification tests suggested by Arellano and Bond (1991), Arellano and Bover (1995), and Blundell and Bond (2000). The first is the Sargan test that tests the null hypothesis of over-identification restrictions apply or instruments as group are exogenous.

This test proves or rejects the overall validity of instruments by analyzing the sample analog of moment conditions used in the estimation process. The second test examines the null hypothesis that autocorrelation does not exist, which means that the error terms are not serially correlated. In the difference regression, we test whether the differenced error term is in first order or in second order serially uncorrelated.

The specification of dynamic panel data model (GMM) is as follows:

$$
\begin{aligned}
G D P_{i t}= & \mu+G_{(i t-1)}+B_{1} \text { DEBT }_{i t}+B_{2} \text { DEBT_SQUARE } \\
& +B_{5} \text { FINAL_CONSUM }_{i t}+B_{4} \text { EXPORT }_{i t}+B_{5} \text { GROSS_SAV }_{i t}+ \\
& +B_{6} \text { CURRENT_ACCOUN } \\
& +B_{7} \text { FINAL_GOVERMENT_EXPEND_it }+ \\
& +\delta_{i}+\gamma_{i}+\varepsilon_{i}
\end{aligned}
$$

The dependent variable is GDP per capita growth rate for each country $i$ and $t$ represents years, $\mu$ is term of constant; explanatory variables include $G D P_{i t-1}$ is the first lag of dependent variable, $D E B T_{i t}$ is debt and $D E B T \_Q U A R E_{i t}$ represents debt square assuming a non-linear relationship between government debt and economic growth. Based on the theoretical assumption that the relationships between public debt and economic growth is non-linear, we expect lower debt to have a positive effect and debt in square to have negative effect on economic growth. We also include and control variables in order to enhance the performance of model and to provide robust result. The control variables are selected based on the main 
determinants of economic growth (see Sala-i-Martin et al., 2004; Kumar and Woo, 2010; Checherita and Rother, 2010). The control variables are final consumption, exports, gross savings, current account and final government expenditures. The term $\delta_{i}$ is the country fixed effect that enables us to control for time-invariant unobservable factors that may affect economic growth which otherwise may lead to bias coefficients. The term $\gamma_{i}$ is the common time effect that covers business cycle effect which otherwise may lead to spurious regression between dependent variable and explanatory variables. The term $\varepsilon_{i t}$ represent standard error.

\section{ii) Panel threshold model}

The relationship between GDP per capita growth and public debt-to-GDP is examined, applying Panel threshold model proposed by Hansen (1999) and Wang (2015). This method allows us to estimate the endogenous threshold level. The specification of the single threshold is the following:

$$
y_{i t}=\mu_{i}+B_{1} X_{i t}+\operatorname{debt} \cdot I\left(q_{i t}<\gamma\right)+B_{2} X_{i t}+\operatorname{debt.I}\left(q_{i t} \geq \gamma\right)+u_{i}+e_{i}
$$

The dependant variable $y_{i t}$ is GDP per capita growth. The threshold variable $q_{i t}$ is the public debt-to-GDP ratio and $\gamma$ is the threshold parameter that divides the equation into two regimes with coefficients $\beta_{1}$ and $\beta_{2} . \mu_{i}$ represents the countryspecific effect. $I($.$) is indicator of function. The parameter u_{i}$ is the individual effect, while $e_{i t}$ is the disturbance. $X$ contains control variables. The equation may also be written

$$
\begin{aligned}
& y_{i t}=\mu_{i}+B_{1} X_{i t}+\operatorname{debt.I}\left(q_{i t} \leq \gamma\right)+e_{i t} i f q_{i t} \leq \gamma \\
& y_{i t}=\mu_{i}+B_{2} X_{i t}+\operatorname{debt.I}\left(q_{i t}>\gamma\right)+e_{i t} i f q_{i t}>\gamma
\end{aligned}
$$

According to Hansen (1999), there are several steps that should be undertaken in order to find threshold. In the first step, the equation is estimated, applying ordinary last-square to determine threshold. Then, we calculate the sum squares residuals (RSS) for all values of the threshold $\gamma$. The sum squared residuals is

$$
S_{1}(\gamma)=[\hat{e}(\gamma)]^{\prime}[\hat{e}(\gamma)]
$$

Following Hansen (1999) in the second step the threshold parameter is calculated by minimizing the sum squared residuals $S_{1}(\gamma)$ as following:

$$
\hat{\gamma}=\arg \min S_{1}(\gamma)
$$


In the third step we estimate the significance of threshold level, i.e., the null and alternative hypotheses. The null hypothesis and alternative hypothesis, i.e., the linear versus the single threshold model are

$$
\begin{aligned}
& \mathrm{H}_{0}: \mathrm{B}_{1}=\mathrm{B}_{2}, \\
& \mathrm{Ha}: \mathrm{B}_{1} \neq \mathrm{B}_{2}
\end{aligned}
$$

Following Hansen (1999) we apply the following likelihood ratio to test of $H_{0}$ :

$$
F_{1}=\frac{S_{0}-S_{1}(\gamma)}{\delta^{2}}
$$

where $S_{0}$ is the sum of squared residuals under $H_{0}$ i.e., the linear model $S_{1}(\hat{\gamma})$ represents the sum of squared residuals under $H_{a}$ i.e., the threshold model. Hansen (1999) showed that the asymptotic distribution of $F_{1}$ is not standard, he however resolved the problem by applying bootstrap procedure to simulate the asymptotic distribution of statistics $F_{1}$.

\section{Empirical data and analysis}

In this section we report descriptive statistics/empirical data and regression results analysis of panel data model and result of panel threshold model regarding the impact of debt-to-GDP ratio on economic growth in the European transition countries.

\subsection{Descriptive statistics}

In this paper we used annual data for a panel of 20 European transition countries, (Central, Eastern and Western Balkans) over the period from 1995 to 2017. In addition, we provide summary statistics for European, Central, Eastern and Western Balkans countries in appendix A, tables A1 to A3. The sources of the data sets are provided by World Bank, International Monetary Fund, and Eurostat. In appendix B are the tables B1 to B6 that contain information on list of countries and description of the variables. The dependent variable is GDP per capita growth rate whereas the independent variables are debt-to-GDP ratio, debt squared that represents debt square assuming a non-linear relationship between government debt and economic growth. We include control variables that are based on the main determinants of economic growth (see Sala-i-Martin, 2004; Kumar and Woo, 2010; Checherita and Rother, 2010). The control variables are final consumption as \% of GDP, exports as \% of GDP, gross savings as \% of GDP, current account as \% of GDP, and final government expenditures as \% of GDP. 


\subsection{The result of panel data model and panel threshold model}

We report the result of the panel data model and threshold value estimation in the transition countries in Central, Eastern and Western Balkans countries in tables 1, 2 and 3 from equations (1) and (2). The estimation results of the panel threshold model are reported in Appendix C, tables $\mathrm{C} 1, \mathrm{C} 2$ and $\mathrm{C} 3$. The results show that all calculated dynamic panel models are well modeled, as the coefficients of lagged real GDP per capita are statistically significant. Furthermore, the Sargan -test for identification restrictions in the presence of heteroscedasticity with the associated p-value which examines the validity of the instrumental variables is accepted (obtained in the second steps result) as healthy instruments for all estimated equations. Therefore, the results from GMM estimator proves the hypothesis that instrumental variables are not correlated with the set of residuals. As a result, Arellano - Bond test AR(1) and AR(2) tests with associated p-values are rejected in the first order while, it is accepted in the second order, which confirms that there is no autocorrelation in the second order between the error term (by construction, the differenced error term is first-order serially correlated even if the original error term is not). The confidence intervals (CI) of the debt turning point are generated through bootstrapping based on a normal distribution, i.e., asymptotically normally distributed. The bootstrap method is based on simulations used to derive the coefficients and calculate the turning points. Confidence intervals are subsequently calculated based on the resulting distribution of the turning points.

\section{(i) Threshold effect of public debt on economic growth in the transition countries of Central Europe}

Table 1 reports the results of the panel data model and threshold value estimation in the transition countries of Central Europe such as Estonia, Lithuania, Latvia, Slovenia, Czech Republic, Poland and Croatia. Employing various econometric techniques, the findings show that all the panel data models have almost same results regarding the effect of debt-to-GDP ratio on GDP per capita growth. However, the significant part of this research is to determine the turning point of the public debt-to GDP ratio. Applying bootstrap method (Hansen 1999), the panel threshold model is estimated, where threshold value is identified (see estimation in Appendix C, Table C1). 
Table 1: Results from regression analysis

\begin{tabular}{|c|c|c|c|c|c|}
\hline Variables & OLS & $\begin{array}{l}\text { Fixed } \\
\text { effects }\end{array}$ & $\begin{array}{l}\text { Random } \\
\text { effects }\end{array}$ & $\begin{array}{c}\text { Hausman- } \\
\text { Taylor } \\
\end{array}$ & GMM \\
\hline $\begin{array}{l}\text { GDP_lag } \\
\text { See }\end{array}$ & & & & $\begin{array}{r}0.1327^{*} \\
(0.091)\end{array}$ & $\begin{array}{r}-0.1799 * * * \\
(0.0072)\end{array}$ \\
\hline $\begin{array}{l}\text { Debt } \\
\text { see }\end{array}$ & $\begin{array}{l}0.0072 \\
(0.192)\end{array}$ & $\begin{array}{r}0.0889 * * \\
(0.012)\end{array}$ & $\begin{array}{r}0.0072 \\
(0.17)\end{array}$ & $\begin{array}{r}0.0646^{*} \\
(0.052)\end{array}$ & $\begin{array}{r}0.1338^{* *} \\
(0.081)\end{array}$ \\
\hline $\begin{array}{l}\text { Debt_Square } \\
\text { See }\end{array}$ & $\begin{array}{r}-0.0783 \\
(0.14)\end{array}$ & $\begin{array}{r}-2.73 * * * \\
(0.003)\end{array}$ & $\begin{array}{r}-0.07832 \\
(0.14)\end{array}$ & $\begin{array}{r}-1.7183^{* *} \\
(0.9168)\end{array}$ & $\begin{array}{r}-5.2434 * * * \\
(1.4561)\end{array}$ \\
\hline Export & $0.033^{*}$ & $0.0968 * *$ & $0.0332 *$ & $0.0834 *$ & $0.279 * * *$ \\
\hline Final_Consum & 0.1116 & -0.0898 & 0.1116 & 0.1228 & $0.5842 * *$ \\
\hline Gross_Saving & 0.0984 & 0.2827 & 0.0984 & 0.2456 & $0.714 * * *$ \\
\hline Current_Account & $-0.45 * *$ & $-0.385^{* *}$ & $-0.470 * * *$ & $-0.360 * * *$ & $-0.5862 * * *$ \\
\hline $\begin{array}{l}\text { Final__ } \\
\text { Government_ } \\
\text { Expenditure }\end{array}$ & $-0.61 * *$ & -0.1449 & $-0.6901 * *$ & $-0.3735^{*}$ & $-0.722 * *$ \\
\hline Constant & 3.22 & 15.75 & 3.22 & -3.92 & \\
\hline Observation & 146 & 146 & 146 & 145 & 138 \\
\hline $\begin{array}{l}\text { Arellano - Bond } \\
\text { test for AR (1) }\end{array}$ & - & (1.97) & - & & (1.97) \\
\hline $\begin{array}{l}\text { Arellano - Bond } \\
\text { test for AR (2) }\end{array}$ & - & $(-3.47)$ & - & & $(-3.47)$ \\
\hline Sargan Test & - & - & - & & $(280.79)$ \\
\hline \multicolumn{6}{|l|}{$X^{2(56) p r o b .}$} \\
\hline $\begin{array}{l}\text { Turning Point } \\
\text { 95\% CI bootstrap } \\
\text { - normal-based } \\
\text { CI }\end{array}$ & & & & & $\begin{array}{r}81.60 \\
(45 ; 82)\end{array}$ \\
\hline
\end{tabular}

Note: GDP Per capita (Economic Growth) is a dependent variable. In all GMM regression are used with robust standard error. Robust standard error in parenthesis, *, **, ***, denote significance at the $10 \%, 5 \%$ and $1 \%$ respectively. Sargan test shows the p-value for null hypothesis of the validity of instruments (obtained second steps result). The AR (1) and AR ( 2) are p-values for first and second order of auto correlated of errors term (obtained in the second order). The confidence intervals (CI) of the debt turning point are generated through bootstrapping based on a normal distribution.

Source: Authors' calculations

Findings show that the turning point of the effect of public debt to GDP ranged from $45 \%$ to $82 \%$, more specifically, turning point is $81.60 \%$. Table 1 report the results of the GMM estimator, one will argue that if the debt to GDP is lower than the turning point, it will have a positive effect on GDP per capita in the transition countries of Central Europe. The results show that, an increase of public debt-to- 
GDP ratio for $1 \%$ will have a positive impact on GDP per capita growth by $0.13 \%$. Furthermore, Debt Square (debt^2) to GDP provides a non-linear impact of debtto- GDP on GDP per capita in the transition countries of Central Europe, this produces a concave (inverted U-shape) relationship between the public debt and the economic growth. The coefficient is statistically significant. The result is consistent with result of Checherita and Rother (2010).

Based on the results, it can be seen that the threshold value or limit of the growth of public debt to GDP ranged from $45 \%$ up to $82 \%$. So, the turning point is $81.60 \%$, which means that below of this level will have a positive impact on economic growth. On the other hand, an increase of public debt to GDP above to this level (turning point) will have a negative impact on economic growth in the transition countries of Central Europe. Each excessive increase of public debt may exacerbate the economic system as well as economic growth in general. The results, is consistent with Keynesian Theory which posits that low level of public debt can lead to economic growth, but may be negatively influenced by the high level of public indebtedness which can be characterized by tax increases, fall in investment, and increased consumption spending. Based on the results of this study, we can conclude that, if public debt grows in the transition countries of Central Europe for long periods, the effects will be negative on economic growth.

As seen from the Table 1, export has a positive impact on economic growth in the transition countries of Central Europe. An increase of export by $1 \%$ its effect will be positive by $0.279 \%$ on economic growth. Furthermore, if the final consumption increases by $1 \%$, it will have a positive effect of $0.584 \%$ on the economic growth. Current account has a negative impact on economic growth, whereas the gross saving has a positive impact on economic growth. These results are consistent with the theory of Harrod and Solow growth theory, which highlighted the positive impact of the gross savings on economic growth in the long term. In addition, the final government expenditure has a negative impact on economic growth and the coefficient is statistically significant. An increase of final government expenditure by $1 \%$, it will have a negative impact on the economic growth by $0.72 \%$ in the transition countries of Central Europe. The coefficient is statistically significant. The result is consistent with result of Adam and Bevan (2005), Cohen (1993), Elmendorf and Mankiw (1999).

\section{(ii) Threshold effect of public debt on economic growth in transition countries of Eastern Europe}

Table 2 shows the results of the panel data model and panel threshold value for transition countries in Eastern Europe such as Bulgaria, Belarus, Hungary, Moldova, Romania, Slovakia and Ukraine. Moreover, we employ different econometric techniques in order to test the relationships between public debt-to GDP ratio and 
GDP per capita in those countries. The result for panel threshold value is estimated, using bootstrap method (see estimation in Appendix C, Table C2).

Table 2: Results from regression analysis

\begin{tabular}{|c|c|c|c|c|c|}
\hline Variables & OLS & Fixed Effects & $\begin{array}{l}\text { Random } \\
\text { Effects }\end{array}$ & $\begin{array}{l}\text { Hausman- } \\
\text { Taylor }\end{array}$ & GMM \\
\hline $\begin{array}{l}\text { GDP_lag } \\
\text { See }\end{array}$ & & & & $\begin{array}{r}0.1441^{* *} \\
(0.083) \\
\end{array}$ & $\begin{array}{r}-0.1538^{* *} \\
(0.081) \\
\end{array}$ \\
\hline $\begin{array}{l}\text { Debt } \\
\text { See }\end{array}$ & $\begin{array}{r}-0.0356 \\
(0.041) \\
\end{array}$ & $\begin{array}{r}0.0192 * * \\
(0.0041) \\
\end{array}$ & $\begin{array}{r}-0.0356 \\
(0.054) \\
\end{array}$ & $\begin{aligned}-0.0311 \\
(0.065) \\
\end{aligned}$ & $\begin{array}{r}0.0466^{* *} \\
(0.0071) \\
\end{array}$ \\
\hline $\begin{array}{l}\text { Debt_Square } \\
\text { See }\end{array}$ & $\begin{array}{r}-0.6817 \\
(0.094) \\
\end{array}$ & $\begin{array}{r}-0.8790 * * * \\
(0.094) \\
\end{array}$ & $\begin{array}{r}-0.6817 \\
(1.036) \\
\end{array}$ & $\begin{array}{l}-0.5011 \\
(0.096) \\
\end{array}$ & $\begin{array}{r}-2.0436 * * \\
(1.021) \\
\end{array}$ \\
\hline Export & 0.0205 & 0.0399* & 0.0205 & 0.0183 & $0.1703 * * *$ \\
\hline Final_Consum & $0.0411 *$ & $0.1191^{*}$ & $0.0411 *$ & $0.0431 *$ & $0.0958 * *$ \\
\hline Gross_Saving & $0.2524 * * *$ & $0.4294 * * *$ & $0.2524 * * *$ & $0.246 * * *$ & $0.5631 * * *$ \\
\hline Current_Account & $-0.0956^{*}$ & $-0.1805^{* *}$ & $-0.0956^{*}$ & $-0.0892 *$ & $-0.1426^{*}$ \\
\hline Final_Goverm_Exp & -0.0120 & -0.0142 & -0.0120 & -0.0268 & -0.0745 \\
\hline Constant & 0.14 & -10.66 & 0.14 & -2.45 & - \\
\hline Observation & 140 & 140 & 140 & 139 & 132 \\
\hline $\begin{array}{l}\text { Arellano - Bond test } \\
\text { for AR (1) }\end{array}$ & - & $(-4.75)$ & - & & $(-4.75)$ \\
\hline $\begin{array}{l}\text { Arellano - Bond test } \\
\text { for AR (2) }\end{array}$ & - & $(-2.16)$ & - & & $(-2.16)$ \\
\hline Sargan Test & - & - & - & & $(148.46)$ \\
\hline \multicolumn{6}{|l|}{$X^{2(56) \text { prob. }}$} \\
\hline $\begin{array}{l}\text { Turning Point } \\
\text { 95\% CI bootstrap } \\
\text { - normal-based CI }\end{array}$ & & & & & $\begin{array}{r}71.90 \\
(71 ; 72)\end{array}$ \\
\hline
\end{tabular}

Note: GDP Per capita (Economic Growth) is a dependent variable. In all GMM regression are used with robust standard error. Robust standard error in parenthesis, *,**,***, denote significance at the $10 \%, 5 \%$ and $1 \%$ respectively. Sargan test shows the p-value for null hypothesis of the validity of instruments (obtained second steps result). The AR (1) and AR ( 2) are p-values for the first and second order of auto correlated of errors term (obtained in the second order). The confidence intervals (CI) of the debt turning point are generated through bootstrapping based on a normal distribution.

Source: Authors' calculations

Table 2 report the results of the OLS, fixed and random effects, Hausman-Taylor and GMM estimator. The results of GMM estimator show that if the debt- to-GDP is below the threshold value, it will have a positive impact on GDP per capita in the transition countries in Central Europe. Findings show that, if the debt-to-GDP ratio increases for $1 \%$, it will in turn lead to a positive impact on GDP per capita growth by $0.046 \%$. The Debt Square (debt^2) to GDP shows a non-linear effect of debt to 
GDP on GDP per capita in the transition countries in Eastern Europe, which is a concave (inverted U-shape) relationship between the public debt and the economic growth. This finding is similar to that of Checherita and Rother (2010).

As seen in Table 2, the turning point of public debt-to-GDP is showed in the interval between $71 \%$ and $72 \%$, namely the turning point value or threshold is established at a level of $71.90 \%$. Therefore, if the debt-to-GDP ratio is lower than this level of the threshold, it will have a positive effect on economic growth. And, vice versa, if the debt-to-GDP ratio is beyond this level, it will have negative effect on economic growth in transition countries of Eastern Europe. We may conclude that, if public debt rises for long periods in those countries, the impact of debt-to GDP ratio will be negative on economic growth.

Table 2 reports the results of other independent variables. The export, gross saving and final consumption have a positive effect on economic growth in transition countries in Eastern Europe, whereas current accounts and final government expenditures have a negative effect on economic growth in those countries. The coefficients are statistically significant, but only the coefficient for final government expenditure is statistically insignificant. This result is consistent with the result of Adam and Bevan (2005), Cohen (1993), Elmendorf and Mankiw (1999).

\section{(iii) Threshold effect of public debt on economic growth in Western Balkans countries}

The regression results of panel data model and threshold value is showed in table 3 for Western Balkans countries such as Albania, Bosna and Herzegovina, North Macedonia, Serbia, Montenegro and Kosovo. As in the transition countries of Central, Eastern Europe, we employ different econometric techniques, in order to find the relationships between the debt-to-GDP ratio and GDP per capita growth in the Western Balkans countries. The estimation of panel threshold model is estimated by applying bootstrap method (Hansen 1999) (see estimation in Appendix C, Table C3).

The level of the threshold is at level of $58.20 \%$, which is ranged between $57.40 \%$ and $64.75 \%$. An increase of debt-to-GDP above the threshold level at $58.20 \%$ will have a negative effect on GDP per capita in the Western Balkans. On the other hand, if the debt-to-GDP ratio will be below the threshold level at 58.20\% will have a positive effect on economic growth. As seen from table 3, the results from GMM estimator shows that an increase of the debt-to-GDP ratio for $1 \%$ it in turn leads to an increase of economic growth by $0.08 \%$ in the Western Balkan countries. The coefficient is statistically significant. Furthermore, the findings show that Debt Square $\left(\mathrm{debt}^{\wedge} 2\right)$ to GDP has a non-linear effect of debt to GDP on GDP per capita in the Western Balkan countries, and thus it produces a concave (inverted U-shape) relationship between the public debt and the economic growth. The coefficient is statistically significant. The result is consistent with result of Checherita and Rother (2010). 
Table 3: Results from regression analysis

\begin{tabular}{|c|c|c|c|c|}
\hline Variables & OLS & $\begin{array}{l}\text { Fixed } \\
\text { Effects }\end{array}$ & $\begin{array}{l}\text { Random } \\
\text { Effects }\end{array}$ & GMM \\
\hline $\begin{array}{l}\text { Gdp_Lag } \\
\text { Se }\end{array}$ & & & $\begin{array}{l}0.013 * * \\
(0.0076)\end{array}$ & $\begin{array}{r}-0.0419^{*} \\
(0.00295)\end{array}$ \\
\hline $\begin{array}{l}\text { Debt } \\
\text { Se }\end{array}$ & $\begin{array}{r}0.014 * \\
(0.00816)\end{array}$ & $\begin{array}{r}0.0849 * * \\
(0.00170)\end{array}$ & $\begin{array}{l}0.0183^{*} \\
(0.0076)\end{array}$ & $\begin{array}{l}0.0846^{* *} \\
(0.00215)\end{array}$ \\
\hline $\begin{array}{l}\text { Debt_Square } \\
\text { Se }\end{array}$ & $\begin{array}{r}-0.02 * \\
(-0.0004) \\
\end{array}$ & $\begin{array}{r}-0.04 * * * \\
(-0.0075) \\
\end{array}$ & $\begin{array}{l}-0.002 * \\
(-0.001)\end{array}$ & $\begin{array}{r}-0.0004 * * \\
(-0.0001) \\
\end{array}$ \\
\hline Export & $-0.025 * *$ & $0.7009 *$ & $-0.02 * *$ & $0.0794 *$ \\
\hline Final_Consum & $0.0951 * *$ & $0.1212 *$ & $0.09 * * *$ & $0.1264 * *$ \\
\hline Gross_Saving & $0.254 * *$ & $0.2355^{* * *}$ & $0.247 *$ & $0.252^{* * *}$ \\
\hline Current_Account & $-0.15^{* * *}$ & $-0.1083 * *$ & $-0.14 * *$ & $-0.1064^{*}$ \\
\hline Final_Government_Exp & $0.1081^{*}$ & $0.0979 * * *$ & $0.096^{* *}$ & $0.1382 * *$ \\
\hline Constant & $-12.41 * *$ & $-19.64 * *$ & $-12.29 *$ & - \\
\hline Observation & 106 & 106 & 105 & 98 \\
\hline Arellano - Bond test for AR (1) & - & $(0.000)$ & - & $(0.000)$ \\
\hline Arellano - Bond test for AR (2) & - & $(0.363)$ & - & $(0.363)$ \\
\hline Sargan Test & - & - & - & $(24.543)$ \\
\hline$X^{2(56) p r o b .}$ & & & & $(0.8123)$ \\
\hline $\begin{array}{l}\text { Turning Point } \\
95 \% \text { CI bootstrap } \\
\text { - normal-based CI }\end{array}$ & & & & $\begin{array}{r}58,20 \\
(57 ; 65)\end{array}$ \\
\hline
\end{tabular}

Note: GDP Per capita (Economic Growth) is a dependent variable. In all GMM regression are used with robust standard error. Robust standard error in parenthesis, *, **, ***, denote significance at the $10 \%, 5 \%$ and $1 \%$ respectively. Sargan test shows the p-value for null hypothesis of the validity of instruments (obtained second steps result). The AR (1) and AR (2) are p-values for first and second order of auto correlated of errors term (obtained in the second order). The confidence intervals (CI) of the debt turning point are generated through bootstrapping based on a normal distribution.

Source: Authors' calculations

As seen from the Table 3, export has a positive impact on economic growth in the Western Balkans countries. An increase of export for $1 \%$ will have a positive effect on economic growth by $0.0794 \%$. Moreover, if the final consumption will increase for $1 \%$, it will have a positive effect of $0.1264 \%$ on the economic growth. Current account has a negative impact on economic growth, whereas the gross saving has a positive impact on economic growth. These results are consistent with the theory of Solow growth model, which claimed that the gross savings has a positive on economic growth in the long term. In addition, government expenditures have a positive coefficient estimated by GMM estimator, which means that if the government expenditures will increase by $1 \%$ it will have a positive effect by $0.1382 \%$ on economic growth. The coefficient is statistically significant. 


\section{Results and discussion}

This paper empirically examines and assess the effect of debt-to- GDP ratio on economic growth and identify and determine the threshold values of debtto GDP ratio in the European transition countries from 1995 to 2017 (both years inclusive). Determining the threshold values of debt-to-GDP ratio for European transition countries, this study gives us an important understanding of the current indebtedness situation of public sector. The result, across all dynamic panel regression models reveals that the connection between levels of the debt-to-GDP ratio and economic growth has a nonlinear and a concave (U-shape) relationship with threshold values of debt-to-GDP ratio. The dynamic panel regression results show that at low levels debt-to-GDP ratio has a positive effect on economic growth, whereas beyond a certain threshold value debt-to-GDP ratio has a deleterious effect on economic growth for the European transition countries.

The most important result of the paper is the findings of the public debt threshold values of $81.60 \%, 71.90 \%$ and $58.20 \%$ of GDP, which is an average for all transition countries of Central Europe, Eastern Europe, and Western Balkans countries, respectively. The public debt-to-GDP ratio, which is above the threshold value of GDP is associated, on average, with lower long-term growth. Public debt-to-GDP ratio below the threshold values are associated, on average, with higher long-term economic growth in the respective countries of European transition economies. The result is in line with general theoretical assumption and previous literature. Our investigation of debt and economic growth in European transition countries leads to the implication that there is a clear linking: higher debt is bad for economic growth. In addition, targeting with higher debt-to-GDP ratio to stimulate economic growth is not a good policy option, because it may lead to tax increases, a decrease in private investment, and increased consumption spending. Furthermore, the results suggest that for some European countries in transition current debt levels may already have a negative impact on GDP growth, given the fact that the average debt-to-GDP ratios are currently at levels higher than the public debt threshold value of GDP estimated for European transition countries. The 2017 data show that public debt as part of the GDP in European transition countries have already reached or exceeded the threshold value of GDP. For example, in Slovenia public debt as part of the GDP is $74.1 \%$, in Croatia it is $77.5 \%$, Hungary $(72.9 \%)$, Ukraine $(71.3 \%)$, Albania (71.8\%), Serbia (62.5\%), and Montenegro (67.2\%). However public debt as part of the GDP is below the threshold value in other European transition countries such as Estonia, Lithuania, Latvia, Czech Republic, Poland, Bulgaria, Belarus, Moldova, Romania, Slovakia, Bosna and Herzegovina, North Macedonia and Kosovo. The European transition countries with higher debt levels than threshold must consider in reducing their public debt up to condition that national income is enough to pay back the debt. If the countries are not able to pay back the debt and need additional sources of financing, increasing a tax rate to replace the debt is not a good option. 
Thus, the government should create friendly business environment in order to attract more investments in supporting the economic growth.

The scientific contribution of this study to the current empirical evidence is twofold, first, there is only a handful of empirical studies that have addressed the threshold of public debt-to-GDP ratio, and its effect on economic growth in the European transition countries. Second, we have shown that a different threshold value of debt-to-GDP ratio exists among European transition countries. This suggests that the more developed European transition economies may have a higher debt-to-GDP ratio threshold values than the less developed transition economies. To the best of our knowledge, this is first study that has examined and assessed with clear methodology, the threshold value of the debt-to-GDP ratio that exists in the different transition European countries, more specifically, in Central Europe, Western Europe, and Western Balkans countries.

The study is useful for governments of the European transition countries, since it provides them with useful information about the level of public debt, i.e. the point at which the positive effects of public debt on economic growth turn to be negative. In addition, the study provides valuable information and additional warning signal to policymakers/governments in the European transition countries that targeting with a higher debt level to support growth is not a viable policy option. The European transition countries with debt levels above GDP turning points need to take measure to not/just stabilize public debt but to place it on a downward trajectory in the medium and long term. So that, the only wise strategy for policymakers of European transition countries is to maintain public debt at levels below the debt-toGDP threshold values in order to withstand the unpredictable external shocks that may hit the economies.

\section{Conclusion}

The findings of this empirical study, on European transition economies for the period from 1995 to 2017 (both years inclusive), has revealed that at a low level, the impact of public debt is positive on economic growth, however, this effect turns negative beyond a certain point. Thus, the results suppose $\mathrm{H} 1$, which is in line with the general theoretical assumption on public debt which posits that a higher public debt, all else being constant, is harmful for economic growth. The accumulated public debt beyond the debt-to-GDP level, where the positive effect inverts to a negative effect on economic growth, is $81,60 \%$ for Central Europe, $71,90 \%$ for Eastern Europe and $58.20 \%$ for countries in the Western Balkan region.

We also find support for $\mathrm{H} 2$ which theorizes that the threshold value of debt-toGDP ratio is lower for less developed European transition countries than it is for the developed European transition countries. H2 could be viewed as a new contribution 
of this study. To the best of our knowledge, this is the first and only empirical study that has employed the panel threshold model and found debt-to-GDP threshold values for three sub-groups for European transition countries. The result is in line with previous empirical evidence on developed and emerging countries.

In view of the fact that many European transition countries already have debt levels that are higher than level than threshold level given their GDP, the only possible sound economic advice for those countries is quickly take conclusively actions and measure to address their fiscal problems. The longer, they wait, the bigger the negative impact the debt will have on economic growth which will make it harder, in the future, to undertake measures that will lead to fiscal consolidation. A word of caution for European transition countries that have experienced positive effect of public debt on economic growth; they too need to be careful in designing their fiscal policies, periodically examine their debt levels to ensure that they maintain the appropriate debt-to-GDP ratio, and borrow only for productive public purpose. Failure to manage debt and use it for only productive purposes may turn a positive effect of debt on economic growth to negative effect.

We conclude, based on the results of this study, that different sub-groups of the European transition countries should design their own fiscal initiative to fight higher level of debt in order to support economic growth. Increasing higher tax rate to replace debt level is not a good strategy for the governments of all European transition countries, particularly for the low national income countries. They may have to undertake other fiscal initiatives and measures to boost private sector as an engine of economic growth.

Despite the insights gained from the current study, lack of data in some of the transition countries was a major limitation. Furthermore, this study could be extended by investigating the impact of public debt that may indirectly affect economic growth, and also by investigating the conditions and mechanisms through which public debt will reduce economic growth.

\section{References}

Afonso, A., Alves, J. (2015) 'The Role of Government Debt in Economic Growth', Hacienda Pública Española, Review of Public Economics, Instituto de Estudios Fiscales, Vol. 215, No. 4 , pp. 9-26, doi:10.7866/HPE-RPE.15.4.1.

Adam, C, S., Bevan, D, L. (2005) 'Fiscal deficit and growth in developing countries', Journal of Public Economics, Vol. 89, No. 4, https://doi.org/10.1016/j.jpubeco. 2004.02.006.

Arellano, M, Bond, S. (1991) 'Some Tests of Specification for Panel Data: Monte Carlo Evidence and an Application to Employment Equations' The Review of 
Economic - Studies, Vol. 58, No. 2, pp. 277-297, http://www.jstor.org/stable/ 2297968.

Arellano, M, Bover, O. (1995) 'Another look at the instrumental variable estimation of error- components models', Journal of Econometrics, Vol. 68, No. 1 pp. 29-51, https://doi.org/10.1016/0304-4076(94)01642-D.

Baldacci, E, Kumar, M.S., (2010) 'Fiscal Deficits, Public Debt, and Sovereign Bond Yields', IMF Working Paper Fiscal Affairs Department, Working Paper No. 10/184, pp. 1-30, doi: 10.5089/9781455202188.001.

Baum, A., Checherita-Westphal, C., Rother, P. (2013) 'Debt and Growth: New Evidence for the Euro Area', Journal of International Money and Finance, Vol. 32, pp. 809-821, http://dx.doi.org/10.1016/j.jimonfin.2012.07.004.

Bexheti A., Sadiku L., Sadiku M. (2020) 'The Impact of Public Debt on Economic Growth: Empirical Analyses for Western Balkan Countries', In: JanowiczLomott M., Łyskawa K., Polychronidou P., Karasavvoglou A. (eds) Economic and Financial Challenges for Balkan and Eastern European Countries, Proceedings in Business and Economics, Springer, Cham, https://oi.org/ 10.1007/978-3-030-39927-6_2.

Blundell, R, Bond, S. (1998) 'Initial conditions and moment restrictions in dynamic paneldata models', Journal of Econometrics, Vol. 87, No. 1, pp. 115-143, https:// doi.org/10.1016/S0304-4076(98)00009-8.

Blundell, R, Bond, S. (2000) 'GMM Estimation with Persistent Panel Data: An Application to Production Functions', Econometric Reviews, Vol. 19, No. 3, pp. 321-340, https://doi.org/10.1080/07474930008800475.

Blundell, R., Bond, S., Windmeijer, F. (2000) 'Estimation in Dynamic Panel Data Models: Improving on the Performance of the Standard GMM Estimator', Advances in Econometrics, Vol. 15, No. 2, pp. 53-91, http://dx.doi.org/10.1016/ S0731-9053(00)15003-0.

Checherita, C., Rother, P. (2010) 'The Impact of high and growing government Debt on Economic Growth an Empirical Investigation for the Euro Area', European Central Bank, Working papers series, No. 1237, https://www.ecb. europa.eu/pub/pdf/scpwps/ecbwp1237.pdf.

Cohen, D. (1993) 'Low Investment and Large LDC Debt in the (1980s)', American Economic Review, Vol. 83, No. 3, pp. 437-449, https://www.jstor.org/stable/ 2117527.

Egert, B. (2013) 'The 90\% Public Debt Threshold: The Rise and Fall of a Stylised Fact, Economics Department', Working Papers, No. 1055, pp. 1-30, h t t p : / / www.oecd.org/officialdocuments/publicdisplaydocumentpdf/?cote $=\mathrm{ECO} /$ WKP(2013) $47 \&$ docLanguage $=$ En.

Elmendorf, D.W., Mankiw, G.N. (1999) 'Government Debt Published: Handbook of Macroeconomics', Vol. 1, Taylor, J.B. and M. Woodford, eds., Elsevier Science, B.V., pp. 1615-1699, doi: 10.3386/w6470. 
Gnegne, Y., Jawadi, F. (2013) 'Boundedness and nonlinearities in public debt dynamics', Economic Modelling, No. 34, pp. 154-160, https://doi.org/10.1016/j. econmod.2013.04.006/.

Ghosh, A. et al. ( 2013) 'Fiscal Fatigue FiscalSpace and Debt Sustainability in Advanced Economies', Economic Journal, vol. 0, pages F4-F30.

Hansen, B., (1999) 'Threshold effects in non-dynamic panels: Estimation, testing, and inference', Journal of Econometrics, vol. 93, pp. 345-368, https://doi. org/10.1016/S0304-4076(99)00025-1.

Irons, J., Bivens, J. (2010) 'Government Debt and Economic Growth', Economic Policy Institute, Briefing Paper, No. 271, pp. 1-9, https://www.epi.org/ publication/bp271.

Kumar, M. S., Woo J., (2010) 'Public Debt and Growth', IMF Working Papers, No. 10/174, pp.1-47, https://www.imf.org/external/pubs/ft/wp/2010/wp10174.pdf.

Mencinger, J., Aristovnik, A., Verbic, M. (2015) 'Revisiting the Role of Public Debt in Economic Growth: The Case of OECD Countries', Inzinerine EkonomikaEngineering Economics, Vol. 26, No. 1, pp. 61-66, doi: http://dx.doi.org/ 10.5755/j01.ee.26.1.4551.

Panizza, U., Presbitero, A. F. (2014) 'Public Debt and Economic Growth in Advanced Economies', A Survey, Mo Fir Working Paper, No. 78, Ancona, Italy: MoFiR, Research group (Mo.FiR.) - Univ. Politecnica Marche - Dept. Economic and Social Sciences, http://docs.dises.univpm.it/web/quaderni/ pdfmofir/Mofir078.pdf.

Panizza, U., Presbitero, A. F. (2013) Public Debt and Economic Growth in Advanced Economies: A Survey, Swiss Journal of Economics and Statistics, Vol. 149, pp. 175-2014, https://doi.org/10.1007/BF03399388.

Pescatori, A., Sandri, D., Simon, J. (2014) 'Debt and Growth: Is There a Magic Threshold', IMF Working Paper, No. 14/34, pp. 1-19, https://www.imf.org/ external/pubs/ft/wp/2014/wp1434.pdf.

Rankin, N., Roffia, B. (2003) 'Maximum sustainable government debt in the overlapping generations model', The Manchester School, Vol. 71, No. 3, pp. 217-241, https://doi.org/10.1111/1467-9957.00344.

Reinhart, C.M, Rogoff, K.S. (2010) 'Growth in a Time of Debt', American Economic Review: Papers \& Proceedings Vol. 100, pp. 573-578, http://www. aeaweb.org/articles.php?doi=10.1257/aer.100.2.573.

Schclarek, A. (2004) 'Debt and Economic Growth in Developing Industrial Countries' Working Papers, No. 34, http://swopec.hhs.se/lunewp/abs/lunewp 2005_034.htm.

Sala-i-Martin, X., Doppelhofer, G., Miller, R. (2004) 'Determinants of Long-Term Growth: A Bayesian Averaging of Classical Estimates (BACE) Approach', American Economic Review, Vol. 94, No. 4, pp. 813-835, http://dx.doi. org/10.1257/0002828042002570. 
Wang, Q. (2015) 'Fixed-effect panel threshold model using Stata', The Stata Journal, Vol. 15, No. 1, pp. 121-134, https://doi.org/10.1177/1536867X1501500108.

Wigger, B. U. (2009) 'A note on public debt, tax-exempt bonds, and Ponzi games', Journal of Macroeconomics, Elsevier, Vol. 31, No. 3, pp. 492-499, https://doi. org/10.1016/j.jmacro.2008.07.003.

Woo, J., Kumar, M. (2015) 'Public debt and growth', Economica, Vol. 82, pp. 705739, https://onlinelibrary.wiley.com/doi/abs/10.1111/ecca.12138. 


\title{
Granični učinak javnog duga na gospodarski rast: empirijska analiza u tranzicijskim zemljama Europe
}

\author{
Besnik Fetai ${ }^{1}$, Kestrim Avdimetaj ${ }^{2}$, Abdylmenaf Bexheti ${ }^{3}$, Arben Malaj ${ }^{4}$
}

\begin{abstract}
Sažetak
$U$ radu se empirijski ispituje $i$ procjenjuje odnos između javnog duga $i$ gospodarskog rasta u europskim tranzicijskim zemljama od 1995. do 2017. (uključujući obje godine). Cilj ovog istraživanja je identificirati i odrediti granične vrijednosti ili opseg u kojem udio javnog duga u BDP-u ima pozitivan učinak na gospodarski rast, a nakon kojeg udio duga u BDP-u negativno utječe na gospodarski rast $u$ tranzicijskim zemljama Europe. $U$ tu svrhu primjenjujemo različite ekonometrijske modele i tehnike kao što su objedinjeni OLS (metoda najmanjih kvadrata), modeli fiksnih i slučajnih učinaka, GMM (generalizirana metoda momenata) $i$ bootstrap metoda kako bismo odredili granične vrijednosti udjela javnog duga u BDP-u. Nalazi dokazuju opću teoretsku pretpostavku da na niskoj razini udio javnog duga u BDP-u pozitivno utječe na gospodarski rast, dok nakon određene prekretnice prevladava negativan učinak na rast $u$ tranzicijskim zemljama Europe. Uz to, rezultati pokazuju različite razine graničnih vrijednosti udjela javnog duga u BDP-u među europskim tranzicijskim zemljama. Do sada je potvrđeno da su granične vrijednosti duga prema $B D P-u$ za manje razvijene tranzicijske zemlje niže u odnosu na razvijenije zemlje Europe. Stoga rezultati pružaju dodatne informacije europskim tranzicijskim zemljama, čija je razina duga iznad praga vrijednosti, kako bi smanjile svoj javni dug i poduprle dugoročne izglede gospodarskog rasta.
\end{abstract}

Ključne riječi: ekonomski rast, javni dug, prekretnica, panel podaci, tranzicijske zemlje Europe

JEL klasifikacija: E60, E69, E011, H63

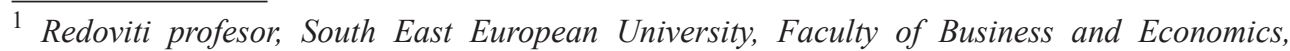
Ilindenska, br. 135, 1200, Tetovo, Republika Sjeverna Makedonija. Znanstveni interest: ekonomija, makroekonomija, monetarna politika, fiskalna politika i ekonometrija. Tel.: +389 71-915-463.E-mail:b.fetai@seeu.edu.mk.

2 Docent, University for Business and Technology, Faculty of Management and Business and Economics, Kalabria Road, 10000, Priština, Republika Kosovo. Znanstveni interes: ekonomija, financijska ekonomija, makroekonomija, ekonometrija. Tel.: +383 45-482-428. E-mail: kestrimavdimetaj@gmail.com.

${ }^{3}$ Redoviti profesor, South East European University, Faculty of Business and Economics, Ilindenska, br. 135, 1200, Tetovo, Republika Sjeverna Makedonija. Znanstveni interes: primijenjena ekonomija, makroekonomija, monetarna ekonomija i javne financije. Tel.: +389 70-364-169.E-mail: a.bexheti@seeu.edu.mk.

4 Redoviti profesor, Institute for Public Policy and Good Governance, University of Tirana, Faculty of Economics, Mother Tereza, br.183, 1001, Tirana, Republika Albanija. Znanstveni interes: javna politika, monetarna ekonomija i financijsko tržište. Tel.: + 355 69-207-4620. E-mail: arben.malaj@gmail.com. 


\section{Appendices}

\section{Appendix A}

Table A1: Descriptive statistics of exogenous and endogenous variables (Central European)

\begin{tabular}{|l|c|r|r|r|}
\hline \multicolumn{1}{|c|}{ Variables } & OBS & \multicolumn{1}{c|}{ Std.Dev } & \multicolumn{1}{c|}{ Min } & \multicolumn{1}{c|}{ Max } \\
\hline GDP & 146 & 49.5293 & -11.83 & 92.12 \\
\hline GDP lag & 146 & 9.5662 & -11.83 & 92.12 \\
\hline Debt & 146 & 25.804 & 9.8 & 224.8 \\
\hline Debt Square & 146 & 1.0179 & 4.5647 & 10.83 \\
\hline Export & 146 & 10.5429 & 5.61 & 55.4 \\
\hline Final Consum & 146 & 10.622 & 80.79 & 138.53 \\
\hline Gross Saving & 146 & 18.1786 & -8.3 & 180.22 \\
\hline Current Account & 146 & 19.5395 & -194.55 & 13.96 \\
\hline Final_Government_Expenditure & 146 & 5.1149 & 9.45 & 39.28 \\
\hline
\end{tabular}

Source: Author's calculation

Table A2: Descriptive statistics of exogenous and endogenous variables (Eastern European)

\begin{tabular}{|l|c|r|r|r|}
\hline \multicolumn{1}{|c|}{ Variables } & OBS & \multicolumn{1}{c|}{ Std.Dev } & \multicolumn{1}{c|}{ Min } & \multicolumn{1}{c|}{ Max } \\
\hline GDP & 140 & 4.7781 & -14.42 & 12.95 \\
\hline GDP lag & 140 & 4.793 & -14.42 & 12.95 \\
\hline Debt & 140 & 22.933 & 8.4 & 136 \\
\hline Debt_Square & 140 & 1.1158 & 4.2564 & 9.8253 \\
\hline Export & 140 & 16.8582 & 22.86 & 96.3 \\
\hline Final_Consum & 140 & 11.6901 & 61.62 & 116.81 \\
\hline Gross_Saving & 140 & 5.0296 & 4.99 & 32.79 \\
\hline Current_Account & 140 & 5.3079 & -25.75 & 10.66 \\
\hline Final_Government_Expenditure & 140 & 3.0117 & 11.63 & 28.81 \\
\hline
\end{tabular}

Source: Author's calculation 
Table A3: Descriptive statistics of exogenous and endogenous variables (Eastern Balkans)

\begin{tabular}{|l|c|r|r|r|}
\hline \multicolumn{1}{|c|}{ Variables } & OBS & \multicolumn{1}{c|}{ Std.Dev } & \multicolumn{1}{c|}{ Min } & \multicolumn{1}{c|}{ Max } \\
\hline GDP & 106 & 49.5293 & -11.83 & 92.12 \\
\hline GDPlag & 106 & 9.5662 & -11.83 & 92.12 \\
\hline Debt & 106 & 25.804 & 9.8 & 224.8 \\
\hline Debt Square & 106 & 1.0179 & 4.5647 & 10.83 \\
\hline Export & 106 & 10.5429 & 5.61 & 55.4 \\
\hline Final_Consum & 106 & 10.622 & 80.79 & 138.53 \\
\hline Gross Saving & 106 & 18.1786 & -8.3 & 180.22 \\
\hline Current Account & 106 & 19.5395 & -194.55 & 13.96 \\
\hline Final_Government_Expenditure & 106 & 5.1149 & 9.45 & 39.28 \\
\hline
\end{tabular}

Source: Author's calculation 


\section{Appendix B}

Table B1: List of the Central Europe countries

\begin{tabular}{|c|c|}
\hline Nr. & Countries of the Central Europe \\
\hline 1 & Estonia \\
\hline 2 & Lithuania \\
\hline 3 & Latvia \\
\hline 4 & Slovenia \\
\hline 5 & Czech Republic \\
\hline 6 & Poland \\
\hline 7 & Croatia \\
\hline
\end{tabular}

Source: Eurostat (https://ec.europa.eu/eurostat), World Bank (https://data.worldbank.org/); International Monetary Fund (https://www.imf.org/en/Data)

Table B2: Description of variables (Central Europe)

\begin{tabular}{|c|l|l|}
\hline Nr. & \multicolumn{1}{|c|}{ Variables } & \multicolumn{1}{c|}{ Code } \\
\hline 1 & GDP (GDP Per Capita -Annual \%) & GDP lag \\
\hline 2 & Public Debt (\% of GDP) & Debt \\
\hline 3 & Debt Square (\% of GDP) & Debt square \\
\hline 4 & Export (\% of GDP) & Export \\
\hline 5 & Final Consumption (\% of GDP) & final_consum \\
\hline 7 & Gross Saving (\% of GDP) & gross saving \\
\hline 8 & Current Account $(\%$ of GDP) & current account \\
\hline 9 & Government Expenditure $\%$ of GDP) & final_government_expenditure \\
\hline
\end{tabular}

Source: Eurostat (https://ec.europa.eu/eurostat), World Bank (https://data.worldbank.org/); International Monetary Fund (https://www.imf.org/en/Data)

Table B3: The list of Eastern Europe countries

\begin{tabular}{|c|c|}
\hline Nr. & Countries of the Eastern Europe \\
\hline 1 & Bulgaria \\
\hline 2 & Belorussia \\
\hline 3 & Hungary \\
\hline 4 & Moldova \\
\hline 5 & Romania \\
\hline 6 & Slovakia \\
\hline 7 & Ukraine \\
\hline
\end{tabular}

Source: Eurostat (https://ec.europa.eu/eurostat), World Bank (https://data.worldbank.org/); International Monetary Fund (https://www.imf.org/en/Data) 
Table B4: Description of the variables (Eastern Europe)

\begin{tabular}{|c|l|l|}
\hline $\mathrm{Nr}$ & \multicolumn{1}{|c|}{ Variables } & \multicolumn{1}{c|}{ Code } \\
\hline 1 & GDP (GDP Per Capita -Annual \%) & GDP lag \\
\hline 2 & Public Debt (\% of GDP) & Debt \\
\hline 3 & Debt Square (\% of GDP) & debt_square \\
\hline 4 & Export $(\%$ of GDP) & Export \\
\hline 5 & Final Consumption (\% of GDP) & final_consum \\
\hline 7 & Gross Saving $(\%$ of GDP) & gross_saving \\
\hline 8 & Current Account $(\%$ of GDP) & current_account \\
\hline 9 & Government Expenditure $(\%$ of GDP) & final_government_expenditure \\
\hline
\end{tabular}

Source: Eurostat (https://ec.europa.eu/eurostat), World Bank (https://data.worldbank.org/); International Monetary Fund (https://www.imf.org/en/Data)

Table B5: List of the Western Balkan countries (Western Europe)

\begin{tabular}{|c|c|}
\hline Nr. & Countries of the Western Balkan \\
\hline 1 & Albania \\
\hline 2 & Bosnia and Herzegovina \\
\hline 3 & Republic of North Macedonia \\
\hline 4 & Serbia \\
\hline 5 & Montenegro \\
\hline 6 & Kosovo \\
\hline
\end{tabular}

Source: Eurostat (https://ec.europa.eu/eurostat), World Bank (https://data.worldbank.org/); International Monetary Fund (https://www.imf.org/en/Data)

Table B6: Description of the variables (Western Balkans)

\begin{tabular}{|c|l|l|}
\hline Nr. & \multicolumn{1}{|c|}{ Variables } & \multicolumn{1}{c|}{ Code } \\
\hline 1 & GDP (GDP Per Capita- Annual \%) & GDP lag \\
\hline 2 & Public Debt (\% of GDP) & Debt \\
\hline 3 & Debt Square (\% of GDP) & debt_square \\
\hline 4 & Export $\%$ of GDP) & Export \\
\hline 5 & Final Consum (\% of GDP) & final_consum \\
\hline 7 & Gross Saving (\% of GDP) & gross_saving \\
\hline 8 & Current Account $(\%$ of GDP) & current_account \\
\hline 9 & Government Expenditure $\%$ of GDP) & final_government_expenditure \\
\hline
\end{tabular}

Source: Eurostat (https://ec.europa.eu/eurostat), World Bank (https://data.worldbank.org/); International Monetary Fund (https://www.imf.org/en/Data) 


\section{Appendix C}

Table C1: Identification of Turning Point in Central Europe

\begin{tabular}{|c|c|c|c|c|c|c|c|}
\hline \multicolumn{8}{|c|}{ Threshold estimator $($ level $=95)$ : } \\
\hline model & \multicolumn{2}{|c|}{ Threshold } & \multicolumn{2}{|c|}{ Lower } & \multicolumn{3}{|c|}{ Upper } \\
\hline Th-1 & \multicolumn{2}{|c|}{81.60} & \multicolumn{2}{|c|}{40.50} & \multicolumn{3}{|c|}{82.30} \\
\hline \multicolumn{8}{|c|}{ Threshold effect test ( bootstrap $=250$ ): } \\
\hline Threshold & RSS & MSE & Fstat & Prob & Crit10 & Crit5 & Crit1 \\
\hline Single & 0.0000 & 0.0000 & -72.16 & 1.0000 & 122.77 & 158.79 & 340.86 \\
\hline
\end{tabular}

Source: Authors' calculations

Table C2: Identification of Turning Point in Eastern Europe

\begin{tabular}{|c|c|c|c|c|c|c|c|}
\hline \multicolumn{8}{|c|}{ Threshold estimator (level = 95): } \\
\hline model & \multicolumn{2}{|c|}{ Threshold } & \multicolumn{2}{|c|}{ Lower } & \multicolumn{3}{|c|}{ Upper } \\
\hline Th-1 & \multicolumn{2}{|c|}{71.90} & \multicolumn{2}{|c|}{71.1} & \multicolumn{3}{|c|}{72.0} \\
\hline \multicolumn{8}{|c|}{ Threshold effect test ( bootstrap $=250$ ): } \\
\hline Threshold & RSS & MSE & Fstat & Prob & Crit10 & Crit5 & Crit1 \\
\hline Single & 980.68 & 11.53 & 20.99 & 0.0000 & 9.76 & 10.88 & 15.49 \\
\hline
\end{tabular}

Source: Authors' calculations

Table C3: Identification of Turning Point in Western Balkans

\begin{tabular}{|c|c|c|c|c|c|c|c|}
\hline \multicolumn{8}{|c|}{ Threshold estimator $($ level $=95)$ : } \\
\hline model & \multicolumn{2}{|c|}{ Threshold } & \multicolumn{2}{|c|}{ Lower } & \multicolumn{3}{|c|}{ Upper } \\
\hline Th-1 & \multicolumn{2}{|c|}{58.20} & \multicolumn{2}{|c|}{57.40} & \multicolumn{3}{|c|}{64.75} \\
\hline \multicolumn{8}{|c|}{ Threshold effect test $($ bootstrap $=250)$ : } \\
\hline Threshold & RSS & MSE & Fstat & Prob & Crit10 & Crit5 & Crit1 \\
\hline Single & 0.0000 & 0.000 & -79.83 & 1.0000 & 65.10 & 131.67 & 167.186 \\
\hline
\end{tabular}

Source: Authors' calculations 